\title{
The influence of socioeconomic status on job and life satisfaction among low-income employees in Johor Local Authorities
}

\author{
Errna Nadhirah Binti Kamalulil, ${ }^{1}$ Siti Aisyah Binti Panatik, ${ }^{1 *}$ Farhan Sarwar ${ }^{2}$ \\ ${ }^{1}$ School of Human Resource Development and Psychology, Faculty of Social Sciences and Humanities, Universiti \\ Teknologi Malaysia, Johor Bahru, Johor - Malaysia, ${ }^{2}$ University of Educatihon, Lahore - Pakistan
}

\begin{abstract}
Many studies have found that a low socioeconomic status has a negative impact on welfare. However, contextual evidence on this issue in Malaysia is scarce. Therefore, this study attempts to quantitatively examine the effect of socioeconomic status on life and job satisfaction among low-income employees working in the public. The Satisfaction with Life Scale (SWLS), Work Domain Satisfaction Scale (WDSS), and Socioeconomic Questionnaire were presented to 265 respondents chosen using a convenience sampling technique. The data were then analyzed using SPSS 26.0 and SmartPLS 3.0 equation modeling. The results show that socioeconomic status had a positive effect on life satisfaction $(\mathrm{t}=4.581 ; \mathrm{p}<.001)$ and job satisfaction $(\mathrm{t}=3.423$; $\mathrm{p}<$ .001). Thus, this study contributes to the provision of better insights into the socioeconomic status factors that determine life and job satisfaction, especially among low-income employees working in the public sector in Malaysia.
\end{abstract}

Keywords: job satisfaction; life satisfaction; low-income employees; socioeconomic status; well-being

\begin{abstract}
Abstrak: Banyak penelitian menemukan bahwa memiliki status sosial ekonomi rendah berdampak pada kesejahteraan negatif. Namun, bukti secara kontekstual tentang masalah ini di Malaysia masih langka dijumpai. Oleh karena itu, penelitian ini berupaya untuk mengkaji pengaruh status sosial ekonomi terhadap kepuasan hidup dan kepuasan kerja di antara karyawan berpenghasilan rendah yang bekerja pada sektor publik di Malaysia secara kuantitatif. Skala Satisfaction with Life Scale (SWLS), Work Domain Satisfaction Scale (WDSS), dan kuesioner sosioekonomi disajikan kepada 265 responden menggunakan teknik convenience sampling. Data kemudian dianalisis menggunakan SPSS 26.0 dan SmartPLS 3.0 pemodelan persamaan. Hasil penelitian menunjukkan bahwa status sosial ekonomi berpengaruh positif terhadap kepuasan hidup $(\mathrm{t}=4,581 ; \mathrm{p}<0,001)$ dan kepuasan kerja $(\mathrm{t}=3,423 ; \mathrm{p}<0,001)$. Dengan demikian, penelitian ini berkontribusi dalam memberikan wawasan yang lebih baik tentang faktor-faktor status sosial ekonomi yang menentukan kepuasan hidup dan kepuasan kerja, terutama pada karyawan berpenghasilan rendah yang bekerja pada sektor publik di Malaysia.
\end{abstract}

Kata Kunci: kepuasan kerja; kepuasan hidup; karyawan berpenghasilan rendah; status sosial ekonomi; kesejahteraan

\footnotetext{
*Corresponding Author: Siti Aisyah Binti Panatik (saisyah@utm.my), School of Human Resource Development and Psychology, Faculty of Social Sciences and Humanities, Universiti Teknologi Malaysia, 81310 UTM Johor Bahru, Johor - Malaysia.
} 


\section{Introduction}

Economic changes pertaining to organizational operations contribute to the economic growth of a country. However, this is strongly intertwined with the fundamental problem of the socioeconomic status of low-income groups (Siwar et al., 2016). Various scholars have conceptualized socioeconomic status differently, depending on their research purpose (Azizi et al., 2017; Liberatos et al., 1988; Oishi et al., 2011). Previous studies have shown that the most frequent measures employed in assessing socioeconomic status are income level, academic level, and occupational status. In Malaysia, low-income groups are categorized based on household income, with such groups regarded as being below the 40\% (B40) group of the Malaysian population, with a maximum monthly net household income of RM 4,849 (Department of Statistics Malaysia, 2020). Even though lowincome employees have been found to contribute $16.5 \%$ to Gross National Income (GNI) in Malaysia (Corporate Malaysia, 2017), the $11^{\text {th }}$ Malaysia Plan (2016 to 2020) presented by the Government of Malaysia revealed an increase of 0.3 million B40 households compared to the $10^{\text {th }}$ Malaysia Plan (2011 to 2015). Due to the demand for economic contributions from low-income employees, changes and adaptations have been forced on low-income employees, which in turn have resulted in negative well-being, both in personal and work domains.

Well-being is described as a state of optimal physical and psychological functioning (Deci \& Ryan, 2008). Bodeker et al. (2020) identify it as a lifelong process that enables people to attain their full potential, cope with everyday stressors, work productively and contribute meaningfully to their families, workplaces, communities, and society. However, Malaysia's happiness index score dropped from $35^{\text {th }}$ place in 2018 to $80^{\text {th }}$ in 2019 in the World Happiness Report, further falling to 82 $2^{\text {nd }}$ place in 2020 (Helliwell et al., 2018, 2019, 2020). In addition, the Malaysian Well-Being Index (MyWI) of 2018 revealed that the lowest well-being in social and economic terms related to family and working life, respectively (Department of Statistics Malaysia, 2019). This index shows the importance of well-being and the need to investigate its risk factors, particularly among lowincome employees and from the aspects of job and life domains. This is in accordance with the notion of Diener (1984), in which the state of well-being is determined by various life domains, including work and non-work ones.

As previously reported, the low socioeconomic status of employees results in lower life (Gokdemir \& Dumludag, 2012) and job satisfaction (Pohlig et al., 2020), signifying that the well-being of low-income employees is affected by their socioeconomic status. Therefore, this study operationalizes well-being as the degree of satisfaction of low-income employees with their job and life, representing work and personal domains.

The utilization of bottom-up theory (Diener, 1984) as the underlying theory in this study explains that subjective well-being is the result of various life domains, including personal, social, economic, and health ones. This notion indicates that when individuals are dissatisfied with the factors contributing to their well-being, this will impair their overall well-being. Therefore, in line with Manstead (2018), this study classifies socioeconomic status in terms of personal-related factors, with economic and academic achievement important components of one's personal identity, 
which is mostly attributed to a clear understanding of where one stands in comparison to others in respect of income and education level. Consequently, the utilization of bottom-up theory could further strengthen the explanation of socioeconomic status as risk factor in determining the positive well-being of low-income employees with regard to their life and job satisfaction levels.

According to the recent work of Yaya (2019) focused on the African continent, households with high socioeconomic status enjoy better health access, which in turn lead to greater satisfaction levels. In the Western context, lower education levels and greater financial strain have been found to be significant factors in predicting overall satisfaction (Aranda \& Lincoln, 2011). Higher socioeconomic status, as measured by higher education level and financial resources, determines positive well-being in varied aspects in life, including levels of happiness and satisfaction (Mafini, 2017; Vera-Villarroel et al., 2015). In addition, Caporale et al. (2015) and Golberstein (2016) found that positive well-being was established when financial resources were strong, which eventually could improve people's emotional state. Nevertheless, the literature on the influence of socioeconomic status on life satisfaction is limited, especially in developing countries such as Malaysia. On that account, this study seeks to address this gap by examining the influence of socioeconomic status on life satisfaction among low-income employees in Johor local authorities.

Recent studies have discussed the importance of having adequate economic resources, as low-income employees from varied organizations have been reported to experience a high degree of job dissatisfaction compared to their higher-paid counterparts (Jiang et al., 2017; Pohlig et al,, 2020). These findings are supported by the work of Mitchell and Esnard (2014), who claim there is a positive relationship between income and job satisfaction levels. This view is consistent with the findings of Hoque (2014), who revealed that the degree of job satisfaction was influenced by socioeconomic status. In spite of these reports, empirical evidence on this issue in the Malaysian context remains scarce. For that reason, this study aims to investigate the influence of socioeconomic status on the job satisfaction of low-income employees in Johor local authorities. Johor state was selected as the study location because it ranks sixth out of 16 Malaysian states in terms of median household income (Department of Statistics Malaysia, 2017) and two-thirds of the B40 group live in urban areas (Economic Planning Unit, 2015). Moreover, Arshat et al. (2018) report that economic pressure is one of the difficulties that the B40 group has to deal with, indicating that socioeconomic status is an important risk factor in predicting the positive life and job satisfaction of low-income employees. The conceptual framework of the relationship between the socioeconomic status and well-being dimensions (i.e., life and job satisfaction) is illustrated in Figure 1 and the developed hypotheses are as follows:

- Hypothesis 1 (H1): Socioeconomic status positively influences life satisfaction.

- $\quad$ Hypothesis 2 (H2): Socioeconomic status positively influences job satisfaction. 
Figure 1

Conceptual Framework

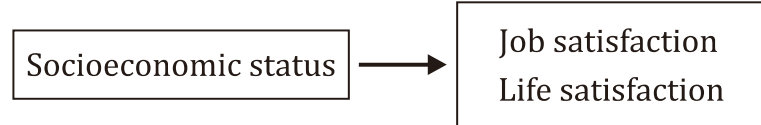

\section{Method}

\section{Research Design}

Quantitative research was used as the research design. The relationships between predictor and outcome variables were examined using a cross-sectional research approach. In addition, a survey questionnaire was utilized as the quantitative research method and hypotheses were developed to explain the link between socioeconomic status and well-being dimensions (i.e., life and job satisfaction).

\section{Population and Sample Size}

The convenience sampling technique was employed due to the global COVID health pandemic, which requires Johor local authority employees to work from home, and also because of restrictions in accessing the employee database. Based on Taherdoost (2016), this technique enables more possibilities to collect a larger sample size, which is relevant in light of the movement restrictions order from the Malaysia government. The study sample were among lowincome employees working at Johor local authorities who earned a maximum net household income of RM 4,849 per month. There were challenges in screening the overall research sample, as the study focuses on low-income employees who are defined by their net household income per month, rather than their individual income. The data collection was successfully conducted in only eight out of the 16 Johor local authorities due to confidentiality concerns. In order to determine the minimum sample size required for the study, GPower software was utilized because the sampling frame of the total number of low-income employees working in the public sector was unattainable. Since the study consists of two predictors, and by using 0.15 effect size and power of 0.95 , the minimum sample size required was 107 . The online questionnaires were distributed to all the low-income employees in the eight Johor local authorities and data were successfully collected from 265 respondents.

\section{Instrument and Measures}

Questionnaires in the form of an online survey using Google Form were used as the medium for collecting the data from the respondents due to the restrictions of movement in which employees are required to work from home during the COVID-19 pandemic. In measuring socioeconomic status, Cowan et al. (2012) claims that there is no universally accepted definition of it. However, the common indicators used in its measurement comprise education level, household income, and occupational level (Domènech-Abella et al., 2018; Engel, 2017; Woodward et al., 2018). However, this study operationalized low-income employees' socioeconomic status through two indicators: education level and household income, excluding 
occupational level, as the study only focuses on administrative officers working for Johor local authorities. Five options were provided for education level, Sijil Pelajaran Malaysia (SPM)/Sijil Tinggi Persekolahan Malaysia (STPM), Malaysian Skills Certificate, Diploma, Bachelor's degree, and Postgraduate degree, in order to determine the highest academic qualification. Net household income per month was also categorized in five options, namely RM < 1,000.00; RM 1,000 - RM 1,999; 2,000 - RM 2,999; RM 3,000 - RM 3,999; and RM 4,000 - RM 4,849 (refer to Table 1).

The items measuring well-being dimensions, namely life and job satisfaction, were adapted from the Satisfaction with Life Scale (SWLS) of Diener et al. (1985) and the Work Domain Satisfaction Scale (WDSS) of Bérubé et al. (2016), both of which consist of five items. SWLS and WDDS were employed to measure well-being from personal (e.g., So far, I have gotten the important things I want in life) and work domains (e.g., Until now, I have obtained the important things I wanted to get from my work). These two instruments are measured using a seven-point Likert scale, ranging from (1) strongly disagree to (7) strongly agree. For each instrument, the total sum of the item scores ranged from 5 (lowest satisfaction) in which if the respondents responded score 1 for all five items to 35 (highest satisfaction) if the respondents responded score 7 for all five items, indicating the higher total sum of the item scores have higher satisfaction level. The reliability of the scale was found to be high for both life and job satisfaction, with Cronbach's alpha coefficients of 0.876 and 0.872 respectively. These good reliability values are in line with the reliability analysis of Diener et al. (1985), which showed that SWLS had a strong reliability of 0.87 , while the reliability for WDSS was also found to be strong ( $\alpha>0.79$ to 0.86 ) (Bérubé et al., 2016).

\section{Data Analysis}

Data from the 265 low-income employees were collected and analyzed using SPSS version 26.0 for the data preparation and to analyze the data descriptively, and in order to obtain more reliable and meaningful outcomes (Fidell \& Tabachnick, 2003). No missing values, double entries or outliers were found, nor irrelevant responses. In term of normality data, these are considered normal if the skewness and kurtosis values range from -3 to +3 (Hair et al., 2010). The normality assessment established normal data, with the range of skewness and kurtosis for life satisfaction $(-0.174 ;-0.545)$ and job satisfaction ($0.098,-0.331$ ) being in the range recommended. Next, common method variance was assessed using the Harman single-factor test, with the results showing that the single factor clarified $46.30 \%$ of the total variance, demonstrating that the data did not generate a common method bias issue.

In performing the inferential analysis, SmartPLS 3.0 structural equation modeling was employed. The first stage focused on assessment of the measurement model, which consisted of reflective and formative measurement models, whose reliability and validity were assessed. The second stage of PLS-SEM emphasized the assessment of the structural model, which was applicable for both reflectively and formatively measuring the constructs. The study referred to the model of assessment criteriafor PLS-SEM stages 1 and 2 developed by Sarstedt et al. (2014) as an inferential analysis guideline. 


\section{Results}

Table 1 shows the respondents' backgrounds, with males dominating the group at $69.1 \%$, and females constituting 30.9\%. Regarding age, the 31 to 35 group was found to be the largest, at 27.5\%. The majority of the respondents were Malay (98.5\%), with 1.5\% Indian. Almost half (44.2\%) had Sijil Pelajaran Malaysia/Sijil Tinggi Pengajian Malaysia as their highest academic qualification. Regarding economic dependents, the respondents have various individuals they were financially responsible for as for monthly house- hold income, this ranged between RM 1,000 and RM 4,849 for $20 \%$ to $30 \%$ of the respondents, while $2.6 \%$ received below RM 1,00 per month.

Table 2 presents the descriptive analysis of the low-income employees' well-being (i.e., life and job satisfaction), including the mean, minimum and maximum values. Life satisfaction was found to have a lower mean (3.71) than job satisfaction (3.93), signifying that the low-income employees felt more dissatisfied with their life than their job.

Table 1

Demographic Profiles

\begin{tabular}{|c|c|c|c|}
\hline Demographic & Details & Frequency $(f)$ & Percentage (\%) \\
\hline Gender & $\begin{array}{l}\text { Male } \\
\text { Female }\end{array}$ & $\begin{array}{c}183 \\
82\end{array}$ & $\begin{array}{l}69.1 \\
30.9\end{array}$ \\
\hline Age (years) & $\begin{array}{l}21-25 \\
26-30 \\
31-35 \\
36-40 \\
41-45 \\
46-50 \\
51-55 \\
56-60\end{array}$ & $\begin{array}{c}27 \\
61 \\
73 \\
42 \\
14 \\
23 \\
20 \\
5\end{array}$ & $\begin{array}{c}10.2 \\
23.0 \\
27.5 \\
15.8 \\
5.3 \\
8.7 \\
7.5 \\
1.9\end{array}$ \\
\hline Race & $\begin{array}{l}\text { Malay } \\
\text { Indian }\end{array}$ & $\begin{array}{c}261 \\
4\end{array}$ & $\begin{array}{c}98.5 \\
1.5\end{array}$ \\
\hline Education Level & $\begin{array}{l}\text { SPM/ STPM } \\
\text { Malaysian Skills Certificate } \\
\text { Diploma } \\
\text { Bachelor's Degree } \\
\text { Postgraduate }\end{array}$ & $\begin{array}{c}117 \\
29 \\
76 \\
38 \\
5\end{array}$ & $\begin{array}{c}44.2 \\
10.9 \\
28.7 \\
14.3 \\
1.9\end{array}$ \\
\hline Economic & 0 & 16 & 6.0 \\
\hline Dependents & $\begin{array}{l}1 \\
2 \\
3 \\
4 \\
5 \\
6 \\
7 \\
8\end{array}$ & $\begin{array}{l}27 \\
57 \\
63 \\
36 \\
29 \\
25 \\
10 \\
2\end{array}$ & $\begin{array}{c}10.2 \\
21.5 \\
23.8 \\
13.6 \\
10.9 \\
9.4 \\
3.8 \\
0.8\end{array}$ \\
\hline Net Household & $<1,000.00$ & 7 & 2.6 \\
\hline Income per & $1,000-1,999$ & 70 & 26.4 \\
\hline Month (RM) & $\begin{array}{l}2,000-2,999 \\
3,000-3,999 \\
4,000-4,849\end{array}$ & $\begin{array}{l}76 \\
54 \\
58\end{array}$ & $\begin{array}{l}28.7 \\
20.4 \\
21.9\end{array}$ \\
\hline
\end{tabular}


Table 2

Descriptive Analysis of Well-being Dimensions of Low-income Employees

\begin{tabular}{lccc}
\hline Construct & Mean & Min. & Max. \\
\hline Life Satisfaction & 3.71 & 1 & 7 \\
Job Satisfaction & 3.93 & 1 & 7 \\
\hline
\end{tabular}

Table 3

Internal Consistency and Convergent Validity

\begin{tabular}{ccccc}
\hline Construct & Loading & Cronbach's Alpha & Composite Reliability & AVE \\
\hline LS1 & 0.868 & & & \\
LS2 & 0.912 & 0.876 & 0.913 & 0.684 \\
LS3 & 0.915 & & & \\
LS4 & 0.838 & & & \\
LS5 & 0.545 & & 0.909 & \\
\hline JS1 & 0.810 & 0.872 & & \\
JS2 & 0.894 & & & \\
JS3 & 0.891 & & & \\
JS4 & 0.849 & & & \\
JS5 & 0.617 & &
\end{tabular}

For the first stage of the inferential analysis, both reflective and formative measurement models were examined. For reflectively measured constructs, outer loadings, Cronbach's alpha, composite reliability and average variance extracted (AVE) were assessed, as recommended by Hair et al. (2014). The cut-off values of all the assessments should be greater than 0.7, apart from the AVE of convergent validity, which should be over 0.5 (Hair et al., 2011). However, Hair et al. (2011) claim that outer loadings with a value equal and greater than 0.4 should be regarded as adequate, providing that the items converge with each other. Based on the results of the assessments shown in Table 3 , all the values were found to be above the thresholds, indicating adequate reliability and convergent validity.

For the discriminant validity assessment, the Fornell-Larcker criterion was used. Fornell and
Larcker (1981) recommend that the construct shares greater variance with its respective indicators than other constructs in the model. Table 4 shows the output of the Fornell-Larcker criterion between the square roots of the AVE values with the constructs. That the square root of AVEs on the bolded diagonal are higher with their corresponding construct compared to the other construct. The result implies that the square roots of AVE values range from 0.819 to 0.827 , which exceeds the off-diagonal elements in their corresponding row and column. Thus, the result indicates that the accepted threshold of the Fornel-Larcker criterion is met.

Overall, the results of the analyses tested on the measurement models are all satisfactory. This indicates that the measurement model for this study is valid and reliable to be used to estimate the parameters in the structural model. 
Table 4

Fornell-Larcker Criterion Analysis Results

\begin{tabular}{lll}
\hline Construct & Life Satisfaction & Job Satisfaction \\
\hline Life Satisfaction & 0.827 & \\
Job Satisfaction & 0.740 & 0.819 \\
\hline
\end{tabular}

Note: The bolded diagonal elements represent the square roots of AVE value and the off-diagonal elements represent the inter-correlation value between constructs.

Table 5

Collinearity, Significance and Relevance of the Outer Weights

\begin{tabular}{lccccccc}
\hline Construct & Indicator & VIF & Weight & t-value & p-value & Loading & Significance \\
\hline \multirow{2}{*}{ SES } & EL & 1.068 & -0.172 & 0.621 & 0.268 & 0.374 & No \\
& HI & 1.068 & 1.029 & 7.377 & $<0.001$ & 0.000 & Yes \\
\hline
\end{tabular}

Note. SES: Socioeconomic status; EL: Education level; HI: Household income

Table 6

Hypothesis Testing

\begin{tabular}{llcccccc}
\hline \multirow{2}{*}{ Hypothesis } & \multirow{2}{*}{ Path } & \multirow{2}{*}{$\beta$} & \multirow{2}{*}{ t-value } & \multirow{2}{*}{ p-value } & \multicolumn{2}{c}{$95 \%$ BCa-CI } & \multirow{2}{*}{ Result } \\
\hline H1 & & & & & & & \\
H2 & SES - LS & 0.260 & 4.581 & $<0.001$ & 0.175 & 0.360 & Supported \\
& SES -> JS & 0.180 & 3.423 & $<0.001$ & 0.101 & 0.276 & Supported \\
\hline
\end{tabular}

Note. SES: Socioeconomic status; JS: Job satisfaction; Life satisfaction

In addition, the study also performed analysis on the formatively measured construct (refer to Table 5), as the significance of the socioeconomic status measure is defined by the indicators, namely education level and household income. The variance inflation factor (VIF) values for both indicators were lower than the cut-off value of 5 , as recommended by Hair et al. (2011), indicating no issue of collinearity in the socioeconomic status construct. Household income was retained in the model because the t-value had a significant value ( $t>1.645$, one-tailed). However, education level was removed due to its non-significant $t-$ value and loading greater than 0.5. Therefore, socioeconomic status was only measured by household income as the formative indicator.
After both the reflectively and formatively measured constructs were assessed and deemed to meet the evaluation criteria, analysis of the structural model was the next step in the PLSSEM evaluation process (Hair et al., 2017). The bootstrapping technique was used to assess the path coefficient significance, with the threshold of the $t$-value needing to be greater than 1.645 and the p-value below 0.05 (one-tailed) (Hair et al., 2011). Table 6 shows the results of the hypothesis testing and indicates that all the path coefficients exhibited positive significant results, namely socioeconomic status and life satisfaction $(\beta=$ $0.260 ; \mathrm{t}=4.581 ; \mathrm{p}<0.001)$ and socioeconomic status and job satisfaction $(\beta=0.180 ; t=3.423 ; p$ $<0.001)$. Hence, $\mathrm{H} 1$ and $\mathrm{H} 2$ are supported. 
Next, Table 7 shows the results of the coefficient of determination $\left(\mathrm{R}^{2}\right)$, effect size ( $\left.\mathrm{f}^{2}\right)$, and predictive relevance $\left(\mathrm{Q}^{2}\right)$. The $\mathrm{R}^{2}$ for life and job satisfaction was 0.064 and 0.029 respectively, which established a weak level (Cohen, 1988), indicating that $6.4 \%$ variance in life satisfaction and $2.9 \%$ variance in job satisfaction were influenced by the socioeconomic status construct.
In addition, the $\mathrm{f}^{2}$ for both relationships obtained a small effect size of 0.02 , as is recommended by Cohen (1988). Moreover, the results of $\mathrm{Q}^{2}$ through the blindfolding technique showed that both of the relationships had established predictive relevance of socioeconomic status on life and job satisfaction. The results of the final research model are shown in Figure 2.

\section{Table 7}

Results of $R^{2}, f^{2}$ and $Q^{2}$

\begin{tabular}{llccc}
\hline Hypothesis & Path & \multicolumn{1}{c}{$\mathrm{R}^{2}$} & $\mathrm{f}^{2}$ & $\mathrm{Q}^{2}$ \\
\hline H1 & SES -> LS & 0.064 (Weak) & 0.072 (Small) & 0.045 (Yes) \\
H2 & SES -> JS & 0.029 (Weak) & 0.034 (Small) & 0.021 (Yes) \\
\hline
\end{tabular}

\section{Figure 2}

Results of the Final Research Model

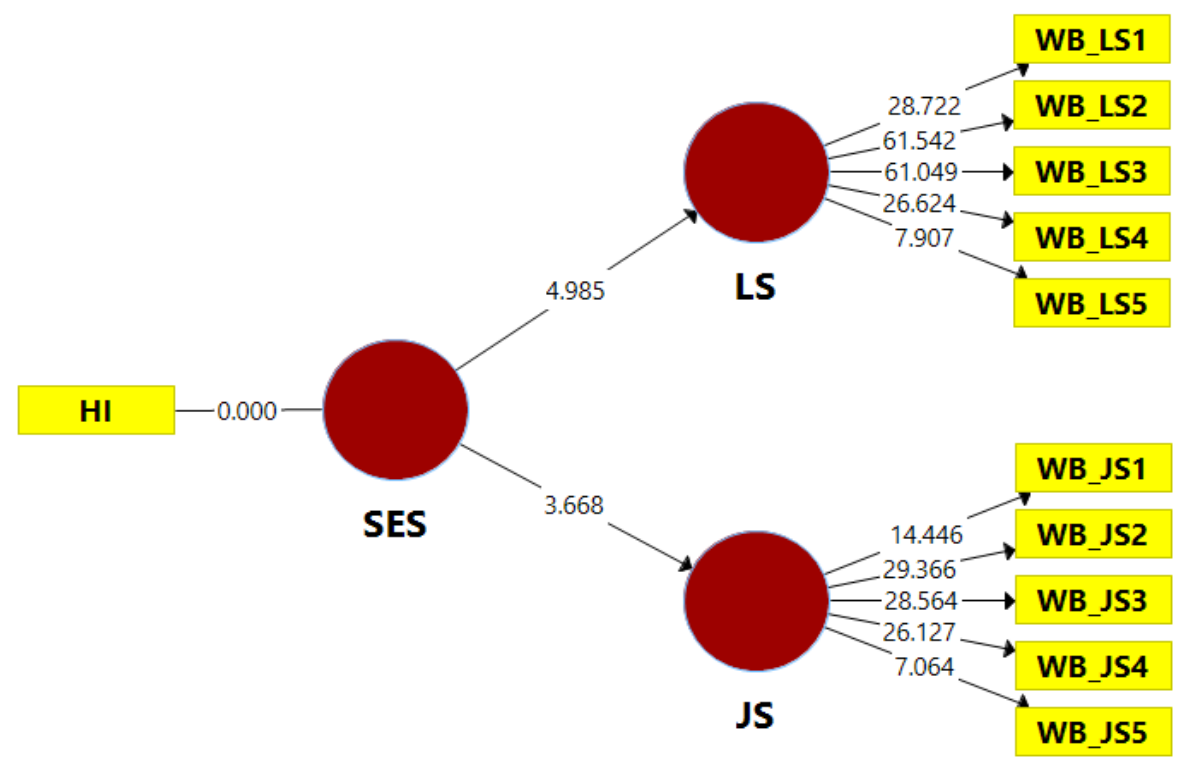




\section{Discussion}

Based on the findings, both life and job satisfaction are significantly and positively influenced by the socioeconomic status of lowincome employees in Johor local authorities. This finding is in line with previous ones that have established a positive association between socioeconomic status and well-being, particularly life and job satisfaction (Golberstein, 2015; Mafini, 2017). Moroever, the finding is also in line with the bottom-up theory of Diener (1984), who explained the socioeconomic factor as one of the personal domains that determines positive wellbeing, including the level of life and job satisfaction. As evident from previous research across disciplines, individuals' degree of life satisfaction is determined by their socioeconomic standing, which includes income earned, occupational prestige and educational attainment (Mafini, 2017; Vera-Villarroel et al., 2015).

A possible explanation for the finding concerns the accessibility to multiple resources. According to Ho et. al., (2016), individuals raised in higher-income households have better access to resources such as finance, education, health, proper nutrition, a comfortable living atmosphere, the capability to purchase material items and opportunities to participate in social activities. In addition, the sufficient resources received by higher-income households are more likely to increase relative happiness compared to those raised in lower-income ones (Douthitt et al., 1992). Additionally, they will acquire security and freedom of choice as a result of their financial well-being, which will positively affect their job and life satisfaction (Präg et al., 2016; VeraVillarroel et al., 2015). As claimed by Mafini (2017), individuals will be more satisfied with their personal and work domains if they have access to a variety of resources that signify their high socioeconomic position. In a study conducted by Arshat et al. (2018) on the stress encountered by low-income groups in the Malaysian context, they found that economic strain was the top stress inducer, followed by emotional and parenting stress, demonstrating that economic issues lead to financial challenges, which in turn result in dissatisfaction with life. The most recent government Malaysia Plan (11 ${ }^{\text {th }}$ Malaysia Plan) has emphasised the necessity to boost income and purchasing power among lowincome groups in order to promote pleasant work and non-work settings. Therefore, the lowincome employees in Johor local authorities will experience greater satisfaction with their life and job if they have sufficient resources, indicating their capability to reach optimum personal, economic and social development.

Interestingly, the finding of this study reveal that socioeconomic status has the strongest influence life satisfaction, followed by job satisfaction. The dominant influence on life satisfaction can be explained through Maslow's hierarchy of needs. According to Maslow (1943), primary needs such as food, clothes, housing, earnings and stable employment, which are categorized as physical needs, must be satisfied first before secondary ones, described as non-material needs. This is consistent with the study of Drakopoulos and Grimani (2013), who reported that there was a positive significant influence of income level on overall happiness. Moreover, the hierarchical approach anticipates that when earnings are extremely low, a large proportion of them will be spent on food to satisfy basic needs, which subsequently will lead to difficulties in fulfilling 
other needs (Drakopoulos \& Grimani, 2017). In addition, the cost of living in cities has become a major concern, specifically for low-income households in Malaysia, which poses significant challenges as a result of service taxes, the rising prices of products and services, and low salaries (Sulaiman et al., 2020) . Surprisingly, the research findings by Rose and Mutsamy (2020) revealed that the low-income group adjusts its lifestyle to the current cost of living by being more economical, purchasing low-quality items and focusing only on what is absolutely required. The findings supporting this research outcome clearly explain that having an adequate income is crucial, because purchasing evolves along the hierarchical order of needs, signifying that lower income employees in Johor local authorities experience low life satisfaction because they have insufficient financial resources to fulfil their needs. Evidently, income level as a measure of socioeconomic status is an influential factor in achieving satisfaction in life among the local authority employees in Johor.

There are several limitations to this study, and the suggestions provided can be used as guidelines for future studies. First, only the employees' education and monthly net household income were used to evaluate their socioeconomic status. Therefore, the incorporation of household wealth, household debt, housing type, housing price per square metre, ratio of size of family house to household size, and facilities and amenities available, such as laptop and vehicle ownership as indicators of socioeconomic class is proposed for further research. In addition, due to time constraints, a cross-sectional study was employed, in which the data were collected and assessed at one time only. For that reason, a longitudinal study focusing on long-term observations of the relationship between socioeconomic status and well-being dimensions is highly recommended in order to obtain more reliable research outcomes. Finally, implementation of the random sampling technique is suggested for future work, as the convenience sampling technique used in this study was unable to generalize the research findings to the entire target population.

\section{Conclusion}

In summary, this paper has discussed the influence of the socioeconomic status of lowincome employees in Johor local authorities on their life and job satisfaction, as dimensions of well-being. The study findings provide a unique contribution to the body of knowledge, as the research has examined the effect of socioeconomic status on personal and work domains at the same time. The analysis indicates a positive association between socioeconomic status and life and job satisfaction, demonstrating the financial strain experienced by low-income employees as an important reason for conducting seminars or workshops related to their well-being. The research findings provide valuable resources for efforts to develop an equitable income distribution which will improve the life and job satisfaction of low-income employees. In practical terms, the government of Malaysia should examine the risk factors of socioeconomic status, specifically in the context of the public sector, by revising income levels, income distribution amongst households, household debt and access to education, as well as healthcare access, in order to cultivate low-income employees' well-being in the personal and job domains. This is in line with 
the $11^{\text {th }}$ Malaysia Plan, which aims to foster the inclusiveness of less privileged groups to achieve an equitable society. Moreover, the work changes encountered by low-income employees, with a reported two-third of Malaysians working from home due to the Movement Control Order (MCO) during the COVID pandemic (Menon, 2021) have resulted in difficulties in balancing the work and non-work domains, for which effective initiatives from top management must be undertaken in relation to well-being, such as providing adequate resources for home office setup and equipment. Therefore, significant contributions have been made to the current academic knowledge of industrial and organizational psychology by providing empirical findings on the influence of socioeconomic status on personal and work domains, namely life and job satisfaction among low-income employees, and by the application of bottom-up theory in describing the elements related to positive well-being in the context of Malaysian low-income employees.

\section{Acknowledgements}

We are grateful for the funding from the Ministry of Higher Education under FRGS, Registration Proposal No: FRGS/1/2019/SS05/ UTM/02/4.]

\section{References}

Aranda, M. P., \& Lincoln, K. D. (2011). Financial strain, negative interaction, coping styles, and mental health among low-income Latinos. Race and Social Problems, 3(4), 280-297. https://doi.org/10.1007/s12552-011-9060-4

Arshat, Z., Pai, F. S., \& Ismail, Z. (2018). Keluarga B40: Tekanan dan kekuatan B40 family: Stress and strength. Journal of Advanced Research in Social and Behavioural Sciences Journal Homepage, 10(1), 91-102.

Azizi, M., Mohamadian, F., Ghajarieah, M., \& Direkvand-Moghadam, A. (2017). The effect of individual factors, socioeconomic and social participation on individual happiness: A cross-sectional study. Journal of Clinical and Diagnostic Research, 11(6), 11-14. https://doi.org/10.7860/ JCDR/2017/24658.9982

Bérubé, N., Donia, M. B. L., Gagné, M., Houlfort, N., \& Lvina, E. (2016). Validation evidence for the work domain satisfaction scale in two languages. International Journal of Psychological Studies, 8(3), 26-39. https://doi.org/10.5539/ijps.v8n3p26

Bodeker, G., Pecorelli, S., Choy, L., \& Guerra, R. (2020). Well-being and mental wellness. Oxford University Press. https://doi.org/10.1093/acrefore/9780190632366.013.162

Caporale, G. M., Georgellis, Y., Tsitsianis, N., \& Yin, Y. P. (2015). A study: Income and happiness across Europe: Do reference value matter? Journal of Economic Psychology, 30(1), 42-51. https://doi.org/https://doi.org/10.1016/j.joep.2008.06.004

Che Rose, R. A., \& Mutsamy, R. (2020). Kenaikan harga barangan dan impaknya terhadap penduduk B40 di Muar, Johor. Asian People Journal (APJ), 3(2), 106-121. https://doi.org/10.37231/ apj.2020.3.2.217

Cohen, J. (1988). Statistical power analysis for the behavioral sciences (2nd ed.). Lawrence Erlbaum Associates.

Corporate Malaysia. (2017). B40 group to contribute 20\% of GNI. The Malaysian Reserve. 
Cowan, C. D., Hauser, R. M., Kominski, R. A., Levin, H. M., Lucas, S. R., Morgan, S. L., Spencer, M. B., \& Chapman, C. (2012). Improving the measurement of socioeconomic status for the national assessment of educational progress: A theoretical foundation.

Deci, E. L., \& Ryan, R. M. (2008). Hedonia, eudaimonia, and well-being: An introduction. Journal of Happiness Studies, 9(1), 1-11. https://doi.org/10.1007/s10902-006-9018-1

Department of Statistics Malaysia. (2017). Press release: GDP by state 2016.

Department of Statistics Malaysia. (2019). Press release: Malaysian well-being index 2018.

Department of Statistics Malaysia. (2020). Press release: Household income \& basic amenities survey report 2019.

Diener, E., Emmons, R. A., Larsen, R. J., \& Griffin, S. (1985). The satisfaction with life scale. Journal of Personality Assessment, 49(1), 71-75. https://doi.org/10.1207/s15327752jpa4901_13

Diener, Edward. (1984). Subjective well-being. Psychological Bulletin, 95(3), 542-575. https://doi.org/10.1037/0033-2909.95.3.542

Domènech-Abella, J., Mundó, J., Leonardi, M., Chatterji, S., Tobiasz-Adamczyk, B., Koskinen, S., AyusoMateos, J. L., \& Haro, J. M. (2018). The association between socioeconomic status and depression among older adults in Finland, Poland and Spain: A comparative cross-sectional study of distinct measures and pathways. Journal of Affective Disorders, 241, 311-318. https://doi.org/10.1016/j.jad.2018.08.077

Douthitt, R. A., Macdonald, M., \& Mullis, R. (1992). The relationship between measures of subjective and economic well-being: A new look. Social Indicators Research, 26(4), 407-422.

Drakopoulos, S. A., \& Grimani, K. (2013). Maslow's needs hierarchy and the effect of income on happiness levels. 1-22.

Drakopoulos, S., \& Grimani, K. (2017). Labor earnings reductions, happiness levels and needs hierarchy. International Journal of Wellbeing, 7(1), 23-39. https://doi.org/10.5502/ijw.v7i1.540

Economic Planning Unit. (2015). B40: What statistics say?

Engel, T. S. (2017). Exploring the relationship between socioeconomic status and health, as it affects men and women. The University of Tennessee at Chattanooga.

Fidell, L. S., \& Tabachnick, B. G. (2003). Preparatory data analysis. In J. A. Schinka, W. F. Velicer, \& I. B. Weiner (Eds.), Handbook of Psychology (pp. 115-142). John Wiley \& Sons, Inc.

Fornell, C., \& Larcker, D. F. (1981). Evaluating structural equation models with unobservable variables and measurement error. Journal of Marketing Research, 1, 39. https://doi.org/10.2307/ 3151312

Gokdemir, O., \& Dumludag, D. (2012). Life satisfaction among Turkish and Moroccan immigrants in the Netherlands: The role of absolute and relative income. Social Indicators Research, 106(3), 407417. https://doi.org/10.1007/s11205-011-9815-8

Golberstein, E. (2015). The effects of income on mental health: Evidence from the social security notch. The Journal of Mental Health Policy and Economics, 18(1), 27-37.

Hair, J. F., Black, W. C., Rabin, B. J., \& Anderson, R. E. (2010). Multivariate data analysis. Prentice-Hall.

Hair, J. F., Hult, G. T. M., Ringle, C., \& Sarstedt, M. (2017). A primer on partial least squares structural equation modeling (PLS-SEM) (2nd ed.). SAGE Publications Inc.

Hair, J. F., Ringle, C. M., \& Sarstedt, M. (2011). PLS-SEM: Indeed a silver bullet. Journal of Marketing Theory and Practice, 19(2), 139-152. https://doi.org/10.2753/MTP1069-6679190202 
Hair, J. F., Sarstedt, M., Hopkins, L., \& Kuppelwieser, V. G. (2014). Partial least squares structural equation modeling (PLS-SEM): An emerging tool in business research. European Business Review, 26(2), 106-121. https://doi.org/10.1108/EBR-10-2013-0128

Helliwell, J. F., Huang, H., \& Wang, S. (2019). Changing world happiness. In The World Happiness Report 2019.

Helliwell, J. F., Huang, H., Wang, S., \& Norton, M. (2020). Social environments for world happiness. In The World Happiness Report 2020.

Helliwell, J. F., Huang, H., Wang, S., \& Shiplett, H. (2018). International migration and world happiness. In The World Happiness Report 2018.

Hoque, M. Z., \& Afrad, M. S. I. (2014). Influences of socio-economic factors on job satisfaction of readymade garments workers. International Journal of Research in Commerce, IT and Management, $4(9), 17-21$.

Jiang, C., Lu, L., \& Lu, J. J. (2017). Socioeconomic factors affecting the job satisfaction levels of selfemployed container truck drivers: A case study from Shanghai Port. Maritime Policy \& Management, 44(5), 641-656. https://doi.org/10.1080/03088839.2017.1326182

Liberatos, P., Link, B. G., \& Kelsey, J. L. (1988). The measurement of social class in epidemiology. Epidemiologic Reviews, 10(1), 87-121. https://doi.org/10.1093/oxfordjournals.epirev. a036030

Mafini, C. (2017). Economic factors and life satisfaction: Trends from South African communities. Acta Universitatis Danubius. OEconomica, 13(3), 155-168.

Manstead, A. S. R. (2018). The psychology of social class: How socioeconomic status impacts thought, feelings, and behaviour. British Journal of Social Psychology, 57(2), 267-291. https://doi.org/ 10.1111/bjso.12251

Maslow, A. H. (1943). A theory of human motivation. Psychological Review, 50(4), 370-396. https://doi.org/10.1037/h0054346

Menon, A. (2021). Press release: Pandemic's impact on Malaysian workforce: 28-country Ipsos survey for the world economic forum.

Mitchell, J. A., \& Esnard, T. R. (2014). Socio-economic factors and job satisfaction among public health care registered nurses in Trinidad and Tobago. International Journal of Business and Social Research, 4(6), 27-37. https://doi.org/10.18533/ijbsr.v4i6.538

Oishi, S., Kesebir, S., \& Diener, E. (2011). Income inequality and happiness. Psychological Science, 22(9), 1095-1100. https://doi.org/10.1177/0956797611417262

Pohlig, M., Israel, S., \& Dingeldey, I. (2020). Does the household context matter for job satisfaction among low-wage workers? Economic and Industrial Democracy, 1-31. https://doi.org/10.1177/ $0143831 X 20975865$

Präg, P., Mills, M. C., \& Wittek, R. (2016). Subjective socioeconomic status and health in cross-national comparison. Social Science \& Medicine, 149, 84-92. https://doi.org/10.1016/ j.socscimed.2015.11.044

Sarstedt, M., Ringle, C. M., Smith, D., Reams, R., \& Hair, J. F. (2014). Partial least squares structural equation modeling (PLS-SEM): A useful tool for family business researchers. Journal of Family Business Strategy, 5(1), 105-115. https://doi.org/10.1016/j.jfbs.2014.01.002

Siwar, C., Ahmed, F., Bashawir, A., \& Mia, M. S. (2016). Urbanization and urban poverty in Malaysia: Consequences and vulnerability. Journal of Applied Sciences, 16(4), 154-160. https://doi.org/ 10.3923/jas.2016.154.160 
Sulaiman, N. F. C., Sanusi, N. A., \& Muhamad, S. (2020). Survey dataset of Malaysian perception on rising cost of living. Journal Data in Brief, 28. https://doi.org/10.1016/j.dib.2019.104910

Taherdoost, H. (2016). Sampling methods in research methodology: How to choose a sampling technique for research. International Journal of Academic Research in Management, 5(2), 18-27. https://doi.org/10.2139/ssrn.3205035

Vera-Villarroel, P., Celis-Atenas, K., Lillo, S., Contreras, D., Díaz-Pardo, N., Páez, D., Torres, J., Vargas, S., \& Ovanedel, J. C. (2015). Towards a model of psychological well-being. The role of socioeconomic status and satisfaction with income in Chile. Universitas Psychologica, 14(3), 1055-1066. https://doi.org/10.11144/Javeriana.upsy14-3.tmpw

Woodward, E. N., Walsh, J. L., Senn, T. E., \& Carey, M. P. (2018). Positive social interaction offsets impact of low socioeconomic status on stress. Journal of the National Medical Association, 110(4), 371377. https://doi.org/10.1016/j.jnma.2017.07.006

Yaya, S., Ghosh, S., \& Ghose, B. (2019). Subjective happiness, health and quality of life and their sociocultural correlates among younger population in Malawi. Social Sciences, 8(2), 1-18. https://doi.org/10.3390/socsci8020055 
This page has been intentionally left blank. 